\title{
A study to explore if dentists' anxiety affects their clinical decision-making
}

Susan Y. Chipchase ${ }^{1}$ BSc, MSc, PhD

Helen R. Chapman ${ }^{2,3}$ BDS, MSc

Roger Bretherton ${ }^{4}$ BSc, DClinPsy

1. Senior Lecturer, School of Psychology, University of Lincoln, Brayford Pool, Lincoln LN6 7TS

2. Visiting Fellow, School of Psychology, University of Lincoln, Brayford Pool, Lincoln LN6 7TS

3. Paul Lowe Dentistry, 31 Farmhouse Way, Monkspath, Solihull B90 4EH

4. Principal Lecturer (Enterprise), School of Psychology, University of Lincoln, Brayford Pool, Lincoln LN6 7TS

*Correspondence to: Mrs Helen Chapman email: hchapman@lincoln.ac.uk 


\begin{abstract}
Aims 1. To develop a measure of dentists' anxiety in clinical situations; 2 . To establish if dentists' anxiety in clinical situations affected their self-reported clinical decision-making; 3. To establish if occupational stress, as demonstrated by burnout, is associated with anxiety in clinical situations and clinical decision-making; and 4. To explore the relationship between decision-making style and the clinical decisions which are influenced by anxiety.

Design Cross-sectional study

Setting Primary Dental Care

Subjects and methods A questionnaire battery (Maslach Burnout Inventory, measuring burnout; Melbourne Decision Making Questionnaire, measuring decision-making style; Dealing with Uncertainty Questionnaire (DUQ), measuring coping with diagnostic uncertainty and a newly designed Dentists' Anxieties in Clinical Situations Scale measuring dentists' anxiety (DACSS-R) and change of treatment (DACSS-C) was distributed to dentists practicing in Nottinghamshire and Lincolnshire. Demographic data were collected and dentists gave examples of anxiety-provoking situations and their responses to them.
\end{abstract}

Main outcome measure Respondents' self-reported anxiety in various clinical situations on a 11-point Likert Scale (DACSS-R) and self-reported changes in clinical procedures (Yes/No; DACSS-C). The DACSS was validated using multiple t-tests and a principal component analysis. Differences in DACSS-R ratings and burnout, decision-making and dealing with uncertainty were explored using Pearson correlations and multiple regression analysis. Qualitative data was subject to a thematic analysis.

Results The DACSS-R revealed a four-factor structure and had high internal reliability (Cronbach's $\alpha=.94$.) Those with higher DACSS-R scores of anxiety were more likely to report changes in clinical procedures (DACSS-C scores). DACSS-R scores were associated with decision-making self-esteem and style as measured by the MDMQ and all burnout subscales, though not with scores on the DUQ scale. Thirty-one percent of the variance in anxiety (DACSS) was explained by Hypervigilance, with an additional $9 \%$ explained by Emotional Exhaustion (MBI) and an additional 2\% by Decision Self-esteem (MDMQ). Thematic analysis of the examples of anxiety provoking situations and means of coping revealed the same structure as found in previous research.

Conclusion Dentists' anxiety in clinical situations does affect the way that dentists work clinically, as assessed using the newly designed and validated DACSS. This anxiety is associated with measures of burnout and decision-making style with implications for training packages for dentists. Theoretically, training to improve decision-making style and reduce anxiety in the surgery could reduce burnout in dentists and improve outcomes for patients. 


\section{Introduction}

There have been many studies exploring the levels of stress in dentists ${ }^{1-4}$. By definition, ${ }^{5} \mathrm{a}$ state of being stressed occurs when one encounters a threatening event which is perceived as being beyond one's ability to cope effectively. In the dental context, stress has been implicitly associated with anxiety and worry-type emotions. However, Chapman and colleagues $^{6-8}$ reported that stress may be accompanied by a variety of negative emotions such as frustration and guilt.

Investigations $s^{1,3,9}$ into the emotional experiences/stress of dentists have previously focused on the significant levels of burnout (a response to the chronic emotional strain of dealing with people, particularly if they have problems ${ }^{10}$ ) which they experience. te Brake ${ }^{11}$ reported that levels of burnout increased from $1997-2001$. In 2008, Denton et al ${ }^{1}$ reported that $8 \%$ of sample of dentists surveyed in the UK had burnout. There are multiple factors associated with the development of burnout including workload, control, monetary reward, social stressors (including from patients) and personal values. ${ }^{12}$

There are 3 aspects to burnout:;3 emotional exhaustion (EE; feelings of being emotionally overwhelmed and exhausted by work), depersonalisation (DP; a cynical, detached feeling towards patients/clients) and a reduced sense of personal achievement (PA; one's sense of professional competence and success). There is some evidence from longitudinal studies ${ }^{14-}$ ${ }^{16}$ that EE occurs first, followed by increasing levels of DP and finally a reduced sense of PA. There is some evidence for a vicious circle where EE predicts DP and also DP predicts EE and PA over time. ${ }^{16}$

Burnout appears to be related to deficits in executive functioning or cognitive control ${ }^{17}$ (working memory, reasoning, problem solving, planning and execution). Clinician burnout can affect the quality and safety of patient care including rates of medical errors, ${ }^{18,19}$ presumably mediated by effects on executive function. There appears to be a doseresponse relationship between the factors. ${ }^{20}$ However, self-reported medical errors are associated with a subsequent worsening of all domains of burnout, suggesting that a vicious circle may be in action. ${ }^{19}$ The cognitive deficits associated with burnout appear to persist beyond apparent clinical recovery and return to work. ${ }^{21}$ This has profound implications for patient safety.

There is very limited experimental evidence ${ }^{22}$ of the effects of stress on intra-operative care. What there is suggests that stress affects performance in surgeons (in particular during highly stressful laparoscopic procedures), that experienced surgeons experience less stress and are consequently less impaired, and that stress impairs surgeons' nontechnical skills such as decision-making and communication skills.

There appear to be no studies of which the authors are aware, of any potential association of stress, anxiety or burnout and either self-reported or experimental effects on clinical decision-making or clinical errors in dentists. However, a link has been established between working demands within the surgery and clinical accidents such as dropping instruments. ${ }^{23}$

Janis and Mann ${ }^{24}$ developed a generic analysis of various styles of decision-making which individuals were prone to use under varying degrees of stress such as increased time pressure. Decisional or cognitive conflict (the simultaneous opposing tendency to accept and reject a particular course of action) results in hesitation, vacillation, feelings of uncertainty and emotional stress which become acute when the decision-maker is aware of the potential losses of a particular course of action. 
Janis and Mann ${ }^{24}$ proposed that there was no such thing as a bad decision, just a bad decision-making process. Decisions are often motivated by the need to protect oneself from anxiety and to nurture one's decisional self-esteem (competence and reputation as a decision-maker). Threats to decisional self-esteem cause psychological stress and attempts to avoid post-decisional regret and anticipated guilt or shame about the decisions made. They define 4 types of decision-making as described in Table 1.

There are more recent models of decision avoidance (see Anderson ${ }^{25}$ for review); however, the vigilant, hypervigilant, buck-passing and procrastination aspects of the Janis and Mann model are assessable using an internationally validated questionnaire; the Melbourne Decision-Making Questionnaire (MDMQ) ${ }^{26,27}$

Decisional conflict has been found to impact on health-related decisions in patients, ${ }^{24,28}$ physicians' clinical decisions ${ }^{29}$ and to form a vicious circle of personal uncertainty in physician-patient interactions. ${ }^{30}$ In an exploration of the effect of burnout on child protection decisions by child protection officers, McGee $^{31}$ found that burned out workers made more rapid decisions, typically based on one piece of information; that neglected children were not at risk. Their decisions were held with greater conviction and unwavering certainty. The authors interpreted this in the light of Janis and Mann's defence avoidance; burned out workers were avoiding involvement in the situation.

Errors in clinical decision-making in the fields of medicine and surgery have been widely discussed, particularly in relation to diagnostic errors. Croskerry ${ }^{32}$ has developed a model of the aetiology of diagnostic errors and this allows for the impact of 'affective states' such as anxiety disorders and mood disorders such as depression on diagnosis. This model appears to have been the subject of very limited empirical evaluation. Poor decision-making processes have been found to lead to poor outcomes. ${ }^{33}$

Schneider et $\mathrm{al}^{34}$ have developed a questionnaire (The Dealing with Uncertainty Questionnaire; DUQ) to evaluate how general medical practitioners deal with uncertainty in clinical practice. This has two subscales 1. Diagnostic Action which evaluates actions taken to clarify diagnostic decision-making e.g. referral to a specialist or ordering more tests and 2. Diagnostic Reasoning which measures the use of intuition, delaying diagnosis and the influence of the patient's social background on diagnosis. Scores on the Diagnostic Action Scale were positively correlated with a measure of anxiety due to uncertainty in clinical situations.

This study aimed to 1 . To develop a measure of dentists' anxiety in clinical situations; 2 . To establish if dentists' anxiety in clinical situations affected their self-reported clinical decisionmaking; 3. To establish if occupational stress, as demonstrated by burnout, is associated with anxiety in clinical situations and clinical decision-making; and 4. To explore the relationship between decision-making style and the clinical decisions which are influenced by anxiety.

The hypotheses were that 1 . dentists' anxieties in clinical situations would affect their selfreported clinical decision-making, 2 . occupational stress, as demonstrated by burnout, would be related to anxiety in clinical situations and changes in clinical decision-making, and 3. dentists' decision-making style (in particular avoidant and hypervigilant decision-making) would be associated with and the clinical decisions which are influenced by anxiety. 


\section{Method}

\section{Questionnaires}

Demographics - This was based on an existing questionnaire ${ }^{35}$ with minor modifications, for example to allow identification for dentists working in the salaried services.

The Maslach Burnout Inventory-Human Services Survey $(\mathrm{MBI}-H S)^{13}$ - This is the most commonly used measurement of burnout, which has been widely used with dentists. ${ }^{1,3}$ It has three subscales measuring 1. emotional exhaustion (EE); 9 items (I feel used up at the end of the workday.) 2. Depersonalisation (DP); 5 items (I've become more callous toward people since I took this job.) and 3. personal achievement (PA); 8 items (I can easily create a relaxed atmosphere with my recipients.) Items are scored on a 6 point Likert scale rating how often the feelings are experienced and anchored 'Never; 0 ' to 'Every day; 6. '

Melbourne Decision-Making Questionnaire (MDMQ) $)^{26,27}$ - This is a well-validated questionnaire which assesses decision-making style as described by Janis and Mann. It has 2 parts. Part one (6 items) assesses decision-making self-esteem (e.g. I feel confident about my ability to make decisions), Part 2 assesses styles of decision-making. There are 4 subscales measuring: vigilance, (6 items; I try to be clear about my objectives before choosing); hypervigilance, (5 items; Whenever I face a difficult decision I feel pessimistic about finding a good solution); procrastination, (5 items; Even after I have made a decision I delay acting upon it); and buck-passing (6 items; I do not like to take responsibility for making decisions). All items are scored on a 3 point scale 0-2 labelled, true, sometimes true, not true ...for me.

Dealing with Uncertainty Questionnaire (DUQ) ${ }^{34}$ - This was developed to measure the impact of uncertainty on the decision-making process of general medical practitioners. The original German text was obtained and translated into German by a native speaker and the text slightly modified to make it applicable to primary care dentists. It consists of 2 subscales; 1. a six item diagnostic action scale (e.g. I frequently refer patients to other doctors/dentists when I am uncertain of a diagnosis) and 2. a six item diagnostic reasoning scale (e.g. Intuition plays a role for me in making diagnostic decisions) It is scored on a six point Likert scale anchored 'strongly agree' and 'strongly disagree.'

Dentists Anxieties in Clinical Situation Scale (DACSS) - A pool of 30 items was generated based on the stressors revealed by previous research. ${ }^{\text {eg } 4,6,7,36}$ The subjective importance of the stressors to dentists, as revealed by a previous study, ${ }^{7}$ influenced the final choice of 20 items for inclusion, which was made by the 3 researchers in committee. For each of the 20 items, dentists were asked to rate their anxiety on an 11 point Likert scale anchored 0 (not at all) \& 10 (the most intense emotion you can experience). For each item they were asked, 'Does the anxiety ever change something about the way you work?' and were asked to indicate yes or no $(\mathrm{Y} / \mathrm{N})$. This resulted in 2 subscales; the DACSS-R which rated anxiety and the DACSS-C which reported change in decision-making.

The questionnaire also asked dentists, 'If you have said that anxiety affects your decisionmaking in some circumstances, can you please describe up to 2 situations or the types of situations when this happened? Please describe the situation and the effect on your decision-making.'

\section{Procedure}

Ethics approval was obtained from the Ethics Committee of the School of Psychology, the University of Lincoln. 
The research method was piloted with 9 volunteer primary care dentists. These dentists were recruited from the volunteer pool of a previous study. ${ }^{7}$ They were sent, by post, a covering letter explaining the nature of the research, a consent form, a questionnaire pack and a prepaid return envelope. Once the forms were returned, $\mathrm{HC}$ contacted the dentists by telephone and asked for feedback on the research pack. Participants suggested moving the DACSS items on ethical conflict to the end of the questionnaire with instructions not to complete those items if the participants were salaried.

A total of 792 dentists whose names appeared on the General Dental Council register for postcodes in the Nottingham, Nottinghamshire, Hull, Lincoln, Lincolnshire and North Lincolnshire areas were contacted by post. This gave a cross-section of dentists working in inner city, suburban and rural areas. Dentists whose addresses specified orthodontic practices and maxillo-facial departments were excluded. Participants were offered a chance to win one of $5, £ 20$ M\&S vouchers. Six weeks after the first send, a second send was posted to 667 dentists. The returns (Table 2) resulted in a final sample of 187 dentists; an overall return rate of $34.1 \%$ and a usable form rate of $23.6 \%$.

Numerical data was entered into SPSS (IBM Statistics, Version 22.0, Armonk, NY). Qualitative data elicited in response to the request for examples was manually transferred, verbatim, to a Microsoft Office 2010 Excel spreadsheet. One researcher (HC) immersed herself in the data by reading and re-reading the entries. It became apparent that they could be analysed using the same thematic framework established in a previous study. ${ }^{7}$ A sample analysis was reviewed by RB.

\section{Results}

187 dentists returned completed questionnaires. Dentists from a range of types of practice, working hours and number of years qualified took part (Table 3). Missing values from the DACSS-R (Rating of anxiety subscale), DUQ, MBI and MDMQ were replaced with that participants mean for that questionnaire, with the exception of R18, R19, R20 from the DACSS-R. The missing values were not replaced for these three items because it is likely that respondents deliberately did not complete these items as they felt they did not apply to them and there was a large number of participants who did not complete these items. There were missing values across these items for 38 of the 187 respondents; 30 respondents did not complete R18, R19 and R20, 7 respondents did not complete R20 and 1 did not complete R18 and R20. Across all the other scales there was no pattern to the missing values, with the exception of the Change in clinical behaviour subscale of the DACCS (DACSS-C); for which missing values were not replaced as answers were categorical No (0) or Yes (1) and it was not clear if missing responses indicated 0 or failure to answer. There was a greater amount of missing data towards the end of this subscale.

\section{What levels of anxiety do dentists experience in primary care dental practice?}

Dentists in primary care dental practice reported experiencing high levels of anxiety from a number of regularly occurring clinical situations. Multiple t-tests revealed that the highest levels of anxiety were reported by those dentists who indicated that the anxiety causes them to change something about the way they work. Across all situations, those dentists who reported that their anxiety caused them to change the way they work reported experiencing more intense levels of anxiety than dentists who reported that anxiety did not change the way they work (Table 4). 
What underlying components can explain the variance in levels of anxiety reported by dentists?

To identify underlying components which might explain the variance in levels of anxiety reported by dentists, a principal component analysis (PCA) with orthogonal rotation was conducted with data from 149 participants on the 20 items from the DACSS-R. Data from 38 participants was excluded as they had not completed items R18-R20. (N.B. An analysis on items 1-17 with 187 participants identified the same pattern of components, the only consequential difference being that item 12 loaded onto component 3 in that analysis, rather than component 2.) One item (Item R3) was identified as having low correlations (<.3) with $45 \%$ of DACSS-R items and was therefore removed from further analysis. To eradicate multicollinearity two items with high correlations (>.6) with $25 \%$ of DACSS-R items were removed from further analysis (Items: R2, R4). The Kaiser-Meyer-Olkin measure verified the sampling adequacy for the analysis, KMO $=0.93$ ('superb' according to Field, 2009 ${ }^{37}$ ), and all KMO values for individual items were $>0.89$, which is well above the acceptable limit of .5 (Field, 2009). Bartlett's test of sphericity $\left(x^{2}(136)=1484.31, p<.001\right)$, indicated that correlations between items were sufficiently large for a PCA. An initial analysis was run to obtain eigenvalues for each component in the data. Three components had eigenvalues over Kaiser's criterion of 1 and in combination explained $63.70 \%$ of the variance. However, examination of the communalities after extraction revealed that for 12 of the 17 items the value was $<.7$, suggesting that Kaiser's rule may not be accurate. According to Jolliffe's criterion (retain components with eigenvalues greater than 0.7), 4 components should be retained. Examination of the scree plot showed inflexions that would justify retaining 3 or 4 components. Therefore, the analysis was rerun specifying the extraction of 4 components. With four components retained, $69.40 \%$ of the variance was explained, therefore the 4component model was chosen. Items were selected for inclusion in a component where the factor loading was greater than 0.4 , where items loaded onto more than one item at greater than 0.4 the greatest component loading was selected. To consider the fit of the model for the data, the reproduced correlation coefficients were examined and compared to the original correlation coefficients. These showed $27 \%$ of the residuals had absolute values greater than 0.05 indicating a good fit of the model. The rotated component matrix shows the component loadings after orthogonal rotation (Table 5). This suggests that component 1 represents uncertainties in clinical practice, component 2 represents threats to sense of control, component 3 represents challenging patients and component 4 represents ethical dilemmas. The DACSS-R had high reliability, Cronbach's $\alpha=.94$. (See Table 5 for $\alpha$ values for subscales).

The levels of reported anxiety from the different components were compared using repeated measures one-way ANOVA which revealed a significant main effect $\left(F_{(2.65,392.41)}=54.18, p<\right.$ .001 , partial eta squared $=.27$ ). Post-hoc t-tests revealed that dentists reported no significant difference between anxiety levels between component 1 and 2 , and significantly less anxiety between all other pairwise comparisons $(p<.001)$. This reflected equally high anxiety for components 1 and 2, and reduced anxiety for component 3, with lowest levels of anxiety for component 4 (Table 6).

\section{Are decision-making style and burnout associated with dentists' anxieties in clinical situations?}

The relationship between decision-making style and anxiety was examined by performing a series of Pearson correlations on average level of anxiety from the DACSS-R and the various subscales of the MDMQ, MBI and DUQ (Table 8). This showed that as decision selfesteem increases and personal accomplishment increases, the level of anxiety decreases, whereas, buck-passing, procrastination, hypervigilance, emotional exhaustion and depersonalisation decrease, as levels of anxiety decrease. Further investigation of the 
relationships between decision-making anxiety style and anxiety was carried out through regression analyses.

\section{Can decision-making characteristics of primary care dentists be used to predict anxiety levels?}

The average score of anxiety ratings on the post PCA DACSS-R (Table 8) was used as a dependent variable in a multiple regression; predictor variables were components of the Melbourne Decision-Making Questionnaire, Maslach Burnout Inventory and Dealing with Uncertainty Questionnaire. (Table 9) An initial enter method multiple regression revealed that Hypervigilance (from the MDMQ), Emotional Exhaustion (from the MBI) and Decision Self-Esteem (from the MDMQ) were significant predictors of anxiety. Therefore, a forward stepwise multiple regression was conducted to identify the explanatory contribution of each of these significant predictors. Thirty-one percent of the variance in anxiety was explained by Hypervigilance, with an additional 9\% explained by Emotional Exhaustion and an additional $2 \%$ by Decision Self-esteem.

\section{Responses to request for examples}

In response to the open-ended request for up to 2 examples of situations where anxiety affected their clinical decision-making, 124 participants provided a total of 172 examples, some of which contained examples of more than one stressor or coping strategy. The thematic system used ${ }^{7}$ consisted of 36 Codes organised into 6 Themes; Emotions expressed by dentists, Negative situations described by dentists, Positive/challenging situations described by dentists, Effects internal to the dentist, Resultant coping strategies, Not pertinent. A summary of the described situations (stressors) appears in Table 10. Some of the examples were obviously prompted by questions on the DACSS, as the question text was referred to in the example.

\section{'Q13 [You receive a solicitor's letter alleging negligence]' [Case 25]}

The effects of anxiety on the dentists' self-reported decision-making (the coping strategies used) are described in Table 11. Again, these overlapped with the coping strategies described in an earlier study. ${ }^{8}$ Some dentists reported that stress was the sole outcome of the event.

'Stress, tension' [Case 586]

Thus it may be seen that these results confirmed the analysis of dentists' stressors and coping responses which were established in previous studies, ${ }^{6-8}$ indicating that the previous results were generalizable to a wider population and provide evidence of validity.

\section{Discussion}

This study reports the development of the Dentists' Anxiety in Clinical Situations Scale (DACSS); the first scale of which the authors are aware, to attempt to quantify the impact of self-reported clinical anxieties (DACSS-R) on clinical working (DASSC-C). This scale shows a high degree of reliability and therefore promise for future use in studies of dentists' anxiety and stress. Gorter et $\mathrm{al}^{38}$ established that there were 49 separate stressors experienced by dentists and Humphris \& Cooper identified still more. ${ }^{39}$ The items included in the DACSS-R were not simply designed to measure stress-evoking situations, but more specifically, anxiety-provoking situations which had been described as important in prompting changes in clinical decision-making by the participants of the previous studies. ${ }^{6-8}$ The constructs underlying the DACSS-R were found to explain nearly $70 \%$ of the variance in anxiety 
suggesting that this is a very useful measure in explaining the particular elements of anxiety which lead to overall feelings of anxiety in dentists.

The regression analysis revealed that the types of situations causing anxiety were summarised under components of; uncertainties in clinical practice, threats to sense of control, challenging patients and ethical dilemmas. The highest levels of anxiety were reported to occur in response to uncertainties in clinical practice and threats to sense of control. These scales make intuitive sense within the clinical environment.

A close relationship was found between anxiety (DASS-R), decision-making style and burnout. Decreased anxiety was associated with higher decisional self-esteem and sense of personal accomplishment; if one is confident in one's belief in one's decision-making effectiveness, one is likely to suffer less anxiety about the decisions taken and gain a greater sense of achievement from work. Increased anxiety (DASS-R) was associated with the avoidant decision-making styles of buck-passing, procrastination, hypervigilance as predicted by the Janis and Mann model. ${ }^{24}$ DASSC-R scores were associated with the burnout characteristics of emotional exhaustion and depersonalisation. Given that burnout is related to deficits in executive functioning (working memory, problem solving, reasoning, planning and execution ${ }^{17}$ ), it is not surprising that burnout scores were related to avoidant and hypervigilant decision-making styles, which are also associated with poor cognitive functioning. ${ }^{40}$ If DACCS-R is viewed as a proxy for state anxiety, this finding confirms previous research in other professional environments, ${ }^{41,42}$ that state anxiety is linked to burnout, though others have not found this link. ${ }^{43}$ Further research into the links between state anxiety, the DACCS and burnout is needed. If one is suffering from EE and DP it is easy to understand how being cut off from and cynical about one's patients could impact on one's anxiety about decisions taken and that anxiety about decisions taken could lead to increased levels of EE and DP, thus forming a vicious circle.

Qualitative examples of the effects on decision-making included modifying the treatment plan, referring on, effects on the treatment given, changes to procedures and interpersonal interactions and effects on the style of decision-making thus confirming previous findings. ${ }^{8}$ It is important to note that this may well be different from the anxiety associated with clinical tasks such as the careful removal of caries in a very deep cavity where the risk of pulpal exposure is high; a situation which should usually provoke vigilant decision-making. This distinction needs to be clarified by further research.

Despite the links demonstrated between DACSS-R and decision-making, it is reassuring to note that, compared to the general population, ${ }^{27}$ the population means for the study were greater for decisional self-esteem and vigilance and lower for avoidant decision-making. This suggests that the clinical training dentists receive ${ }^{44}$ in making diagnostic and clinical decisions is effective and protects patients to a certain extent from the potential impact of dentists' anxieties when working.

The important impact of potential interpersonal disagreements with patients is reflected in the correlation of DACSS-R R4 (Something goes wrong on a patient who is 'difficult') with $25 \%$ of the other items and its consequent removal from the analysis. This might be interpreted as reflecting another layer of ubiquitous stress in addition to the stress of, say, 'A patient doesn't like the appearance of the crowns/ bridgework you are about to fit, which are really very good' (R6) or 'Running late' (R7). Indeed, Schaufeli et al ${ }^{45}$ found that, in primary care physicians, about $75 \%$ of burnout was stable over time and the remaining $25 \%$ was associated with the number of demanding patient visits to which physicians were exposed. Moreover, GPs who attempted to cope with their emotional exhaustion by distancing themselves emotionally from their patients, evoked demanding and threatening behaviour ${ }^{15}$ in what appears to function as a vicious circle. The rise of the 'consumerist' health service is particularly relevant to dentistry where most treatment is (at least partly) paid for ${ }^{46}$ and is likely to fuel this destructive cycle. Similarly, in experimental conditions, being under time 
pressure has been shown to be associated with a deterioration in executive functioning associated with decision-making. ${ }^{40}$ The same 'universality' argument might be made for 'You have to undertake a particularly difficult clinical procedure' (R2).

The weaker multicollinearity of question R3 ('A patient complains about the difficulty of getting appointments.') may reflect the fact that, although it would compound many difficult situations, dentists are often buffered from this by reception and nursing staff.

On first consideration, 'You receive a solicitor's letter alleging negligence' (R 13) may appear to be out of place in the scale 'Uncertainties in clinical practice.' However, dentists report here (Table 1; Case 181] and elsewhere ${ }^{8}$ that receipt of such a letter makes them question their clinical practice and procedures. This suggests episodes of more chronic hypervigilance, usually as a result of complaints and litigation.

I received a solicitor's letter following problems after an extraction on a new patient to the practice, who[m] I was aware had been unhappy with their previous GDP. It has made me cautious and more anxious at treating new patients, particularly those unhappy with their previous GDP and made me try to avoid treatment unless needed. Also reduced confidence in extractions and made me more likely to referlask for help at an early stage. [Case:729]

This level of chronic arousal is also provoked by being obliged to continue to treat patients who have complained. 6,7 The hypervigilance provoked may be more akin to the hypervigilance for threat described in the clinical literature as associated with anxiety disorders and is accompanied by a selective attention to threat. ${ }^{47}$ It has been argued that these phenomena precipitate or maintain a feedforward loop which increases anxiety. ${ }^{48}$ This suggests that a speedy resolution to complaints, no matter where they are handled, is paramount.

The association of DACSS-R score with burnout suggests that burnout is associated with greater anxiety about clinical decisions. The positive association with the buck-passing, procrastination and hypervigilance subscales, and the negative association with the vigilant subscale of the MDMQ, suggests that dentists' anxiety is linked to poor (avoidant) decisionmaking. The weaker relationship with the DUQ diagnostic action scale suggests that dentists may not be fully aware of the impact anxiety is having on their reasoning processes. A previous study ${ }^{8}$ found that dentists would often deny that their emotions, including anxiety, affected their decision-making and then proceeded to describe how it actually changed their clinical approach. The weaker relationship of the DUQ may also reflect a lack of generalisability of the questionnaire from general medical practice. Further research would benefit from the development of a specific measure.

The positive correlation of EE and DP and the negative correlation with the level of, protective, personal achievement, with anxiety in clinical situations suggests that another vicious circle may be operating. Once a practitioner starts to burnout, they may become more anxious in clinical situations, they are then more likely to make avoidant decisions and this may feed forward to fuel anxiety. The results support the findings of $\mathrm{McGee}^{31}$ that burned out social workers took avoidant decisions.

The possible lack of awareness by dentists of the impact of anxiety on their decisions reinforces the impression given in a previous study ${ }^{7}$ in which dentists reported that anxiety did not change their decision-making but then went on to describe exactly how it did so. This leads to the possibility that making dentists more aware of decisional processes would facilitate reflection and improve dentists' decision-making and thus patient outcomes.

Threats to decisional self-esteem are a source of stress. ${ }^{24}$ This study showed that a robust decisional self-esteem was negatively associated with levels of clinical anxieties. It is possible to hypothesise that the ubiquitous stressor of the difficult patient, who is demanding

10 A study to explore if dentists' anxiety affects their clinical decision-making 
and challenges one's clinical decisions, threatens the dentists' sense of decisional selfesteem.

Chambers ${ }^{49}$ has previously suggested that dentists have a 'core need for control' which is threatened by 'uncooperative patients, incompetent staff and government and insurance intrusions.'(p1430) This theme was identified in previous research ${ }^{6,7}$ and is further validated by the emergence of the factor labelled 'threat to sense of control.' The inclusion of item R12 (You have to speak to a dental nurse about changing her procedures in the dental surgery) may reflect that dentists work in idiosyncratic ways and good team work is essential to the efficient running of the surgery; lack of co-operation from the dental nurse would result in stress for the dentist. It may also reflect the pressure of managing staff in order to meet the rigours of contemporaneous standards and guidelines.

Treating anxious and phobic patients has long been noted as a significant stressor ${ }^{36,50}$ and research suggests that some dentists feel ill equipped to help these patients. ${ }^{50}$

The conflicts created by having to charge patients for healthcare, most of which is free at the point of delivery in the UK, are reflected in the scale 'ethical conflicts' and confirms previous findings. ${ }^{6,7}$ The dentists who work largely in NHS practice are more likely to be affected by these issues, though no analysis was undertaken to demonstrate this.

The study had a number of limitations. The return rate of $34.1 \%$, which resulted in a usable form rate of $23.6 \%$, was disappointing and may have impacted on the generalisability of the study. The large number of 'return to sender' items (some received up to 9 months after the deadline for the return of the second questionnaire) suggests that the GDC register is not accurate, resulting in a sampling error beyond the control of the research team. ${ }^{51,52}$ The forms sent to dentists who were retired or not working in primary care, who are largely unidentifiable via the register, resulted in another sampling error beyond the team's control. The offer of entry to a prize draw for one of $5, £ 20$ vouchers, may have been insufficient incentive to dentists to participate. ${ }^{51,52}$ The response rate may have been affected by the length of the questionnaire pack or the attitude of the dentists to the survey. ${ }^{51,52}$ One dentist emailed the researchers to state

'Unfortunately I cannot complete this survey as the question[s] asked in too many cases show a lack of understanding of what actually happens in a dental surgery thus making the answers impossible to answer.'

This attitude may have been fostered by the fact that the questionnaire came from a team based in a University which does not have a tract record in dental research and thus the project may have been viewed as of little value. ${ }^{51,52}$

Return rates could have been improved with a third send, but this was beyond the financial resources of the project.

Despite the low return rate, levels of burnout seen were typical of the population, suggesting the sample was representative. ${ }^{51}$ However, the study warrants replication with a further sample.

The pattern of missing data from the DACCS-C may be for at least 2 reasons; many participants endorsed 'Yes' they did change what they did, to most items. It may have been that they felt that it was unnecessary to keep stating that this happened, or, more likely, the realisation that anxiety made them change how they worked in numerous situations may have been threatening and they felt vulnerable to being perceived as being incompetent because of this. This pattern might be reduced in future by changing the wording of the introduction to assure dentists that changing one's clinical treatment can be highly appropriate and isn't necessarily an indication of incompetence. It would be interesting to 
ask this question of a sample of dentists to establish if this is a possible outcome. Or, more simply, it may have been that, at 20 items, the questionnaire was too long and the participants experienced response fatigue. ${ }^{53}$

The exclusion from the final analysis of salaried dentists, as a result of questions DACSSR18-20, suggests that the study should be replicated with a large sample of this type of dentist as research has shown ${ }^{7}$ that they are subject to additional specific stressors such as working in isolation and being the end point for referral, rather than able to refer on in difficult cases. The decision to group questions R18-20 at the end of the study was based on feedback from the dentists who completed the pilot version of the questionnaire, where the items were interspersed. It is suggested that, in subsequent use of the measure, the instructions for completion of these items is changed from, 'Questions 18-20: Only worked in salaried services? - please ignore,' to Questions 18-20: Never had to charge patients for treatment? - please ignore.' This should minimise the number of salaried dentists who do not complete these items; the caveat must remain as some dentists do not charge patients for care. To remove the items would be to remove questions about significant stressors for the majority of dentists.

The described examples of anxiety provoking situations and consequences for decisionmaking revealed a range of situations including stressors related to patient characteristics, treatment, workload and communication, confirming the factors elicited and described in previous research. ${ }^{6-8,36}$

\section{Conclusion}

This study reports the development of a reliable measure of dentists' anxiety in clinical situations scale (DACSS) which should prove useful in further research into absolute levels of anxiety and in monitoring change following clinical stress interventions for dentists.

The association of DACSS scores with burnout (positively with emotional exhaustion and depersonalisation and negatively associated with personal achievement) suggests that interventions to tackle anxiety may improve burnout and vice versa.

The association of dentists' anxiety with decision-making style (negatively with decisionmaking self-esteem and vigilant decision-making and positively with hypervigilant and avoidant decision-making) implies that improving dentists' abilities to cope with difficult situations may improve decision-making. The much weaker relationship with the decisional action scale of the Dealing with Uncertainty Scale, suggests that the impact of anxiety on dentists' decisions is, at least partly, out of awareness and opens the possibility for interventions to improve decisional awareness and thus patient outcomes.

\section{Acknowledgements}

The authors are indebted to the Shirley Glasstone Hughes Trust for funding this project and to the dentists who gave generously of their precious time. The authors would also like to acknowledge the advice of Professors Leon Mann, Pat Croskerry and Patricia Hollen. 


\section{References}

1. Denton, D.A., Newton, J.T. \& Bower, E.J. Occupational burnout and work engagement: a national survey of dentists in the United Kingdom. Br. Dent J 205, E13-E13 (2008).

2. Cooper, C.L., Watts, J., Baglioni, A.J. \& Kelly, M. Occupational stress amongst general practice dentists. Journal of Occupational Psychology 61, 163-174 (1988).

3. Osborne, D. \& Croucher, R. Levels of burnout in general dental practitioners in the south-east of England. Br. Dent. J 177, 372-377 (1994).

4. Moller, A.T. \& Spangenberg, J.J. Stress and coping amongst South African dentists in private practice. J Dent Assoc S. Afr 51, 347-357 (1996).

5. Lazarus, R.S. \& Folkman, S. Stress, Appraisal, and Coping, (Springer Publishing Company, New York, 1984).

6. Bretherton, R., Chapman, H.R. \& Chipchase, S. A study to explore specific stressors and coping strategies in primary dental care practice. Br Dent J 220, 471-478 (2016).

7. Chapman, H.R., Chipchase, S.Y. \& Bretherton, R. Understanding emotionally relevant situations in primary care dental practice: 1 . Clinical situations and emotional responses. Br Dent J 219, 401-409 (2015).

8. Chapman, H.R., Chipchase, S.Y. \& Bretherton, R. Understanding emotionally relevant situations in primary dental practice. 2. Reported effects of emotionally charged situations. Br Dent J 219, E8 (2015).

9. Gorter, R.C., Albrecht, G., Hoogstraten, J. \& Eijkman, M.A. Professional burnout among Dutch dentists. Community Dent Oral Epidemiol 27, 109-116 (1999).

10. Maslach, C., Schaufeli, W.B. \& Leiter, M.P. Job Burnout. Annual Review of Psychology 52, 397-422 (2001).

11. Te Brake, J.H., Bouman, A.M., Gorter, R.C., Hoogstraten, J. \& Eijkman, M.A. Using the Maslach Burnout Inventory among dentists: burnout measurement and trends. Community Dent Oral Epidemiol 36, 69-75 (2008).

12. Leiter, M.P. \& Maslach, C. Six areas of worklife: a model of the organizational context of burnout. Journal Of Health And Human Services Administration 21, 472-489 (1999).

13. Maslach, C., Jackson, S., E. \& Leiter, M. Maslach Burnout Inventory Manual, (Mind Garden Inc, Menlo Park, California, 1986).

14. te Brake, H., Smits, N., Wicherts, J.M., Gorter, R.C. \& Hoogstraten, J. Burnout development among dentists: a longitudinal study. Eur. J Oral Sci 116, 545-551 (2008).

15. Bakker, A.B., Schaufeli, W.B., Sixma, H.J., Bosveld, W. \& van Dierendonck, D. Patient demands, lack of reciprocity, and burnout: A five-year longitudinal study among general practitioners. Journal of Organizational Behavior 21, 425-441 (2000).

16. Taris, T.W., Le Blanc, P.M., Schaufeli, W.B. \& Schreurs, P.J.G. Are there causal relationships between the dimensions of the Maslach Burnout Inventory? A review and two longitudinal tests. Work \& Stress 19, 238-255 (2005).

17. Deligkaris, P., Panagopoulou, E., Montgomery, A.J. \& Masoura, E. Job burnout and cognitive functioning: A systematic review. Work \& Stress 28, 107-123 (2014).

18. Shanafelt, T.D., et al. Burnout and medical errors among American surgeons. Ann Surg 251, 995-1000 (2010).

19. West, C.P., et al. Association of Perceived Medical Errors With Resident Distress and Empathy. JAMA: The Journal of the American Medical Association 296, 10711078 (2006).

20. Balch, C.M., Freischlag, J.A. \& Shanafelt, T.D. Stress and burnout among surgeons: understanding and managing the syndrome and avoiding the adverse consequences. Arch Surg 144, 371-376 (2009).

21. Osterberg, K., Skogsliden, S. \& Karlson, B. Neuropsychological sequelae of workstress-related exhaustion. Stress 17, 59-69 (2014). 
22. Arora, S., et al. The impact of stress on surgical performance: a systematic review of the literature. Surgery 147, 318-330, 330 (2010).

23. Tsutsumi, A., Umehara, K., Ono, H. \& Kawakami, N. Types of psychosocial job demands and adverse events due to dental mismanagement: a cross sectional study. BMC. Oral Health 7, 3 (2007).

24. Janis, I.L. \& Mann, L. Decision Making: a psychological analysis of conflict, choice, and commitment., (The Free Press, New York, 1977).

25. Anderson, C.J. The psychology of doing nothing: Forms of decision avoidance result from reason and emotion. Psychological Bulletin 129, 139-167 (2003).

26. Mann, L., Burnett, P., Radford, M. \& Ford, S. The Melbourne Decision Making Questionnaire: An Instrument for Measuring Patterns for Coping with Decisional Conflict. Journal of Behavioral Decision Making 10, 1-19 (1997).

27. Mann, L., et al. Cross-cultural Differences in Self-reported Decision-making Style and Confidence. International Journal of Psychology 33, 325-335 (1998).

28. O'Connor, A.M. Validation of a decisional conflict scale. Medical Decision Making: An International Journal Of The Society For Medical Decision Making 15, 25-30 (1995).

29. Dolan, J.G. A method for evaluating health care providers' decision making: The provider decision process assessment instrument. Medical Decision Making 19, 3841 (1991).

30. LeBlanc, A., Kenny, D.A., O'Connor, A.M. \& Legare, F. Decisional conflict in patients and their physicians: A dyadic approach to shared decision making. Medical Decision Making 29, 61-68 (2009).

31. McGee, R.A. Burnout and professional decision making: An analogue study. Journal of Counseling Psychology 36, 345-351 (1989).

32. Croskerry, P., Abbass, A.A. \& Wu, A.W. How doctors feel: Affective issues in patients' safety. The Lancet 372, 1205-1206 (2008).

33. Croskerry, P. Clinical cognition and diagnostic error: Applications of a dual process model of reasoning. Advances in Health Sciences Education 14, $27-35$ (2009).

34. Schneider, A., et al. How do primary care doctors deal with uncertainty in making diagnostic decisions? The development of the 'Dealing with Uncertainty Questionnaire' (DUQ). J. Eval. Clin. Pract 16, 431-437 (2010).

35. Gilmour, J., Stewardson, D.A., Shugars, D.A. \& Burke, F.J. An assessment of career satisfaction among a group of general dental practitioners in Staffordshire. Br. Dent J 198, 701-704, discussion (2005).

36. Gorter, R.C. Stress and Burnout in Dentistry: A Review of the Literature. in thesis 1344 (UVA, 2000).

37. Field, A. Discovering Statistics Using SPSS, (Sage Publications Ltd, London, 2009).

38. Gorter, R.C., Albrecht, G., Hoogstraten, J. \& Eijkman, M.A. Measuring work stress among Dutch dentists. Int Dent J 49, 144-152 (1999).

39. Humphris, G.M. \& Cooper, C.L. New stressors for GDPs in the past ten years: a qualitative study. Br. Dent. J 185, 404-406 (1998).

40. Mann, L. \& Tan, C. The Hassled Decision Maker: The Effects of Perceived Time Pressure on Information Processing in Decision Making. Australian Journal of Management (University of New South Wales) 18, 197 (1993).

41. Turnipseed, D.L. Anxiety and burnout in the health care work environment. Psychological Reports 82, 627-642 (1998).

42. Organopoulou, M., Tsironi, M., Malliarou, M., Alikari, V. \& Zyga, S. Investigation of Anxiety and Burn-Out in Medical and Nursing Staff of Public Hospitals of Peloponnese. International Journal of Caring Sciences 7, 799-808 (2014).

43. Lee, W., Veach, P.M., MacFarlane, I.M. \& LeRoy, B.S. Who is at risk for compassion fatigue? An investigation of genetic counselor demographics, anxiety, compassion satisfaction, and burnout. Journal of Genetic Counseling 24, 358-370 (2015).

44. Khatami, S., MacEntee, M.I., Pratt, D.D. \& Collins, J.B. Clinical Reasoning in Dentistry: A Conceptual Framework for Dental Education. Journal of Dental Education 76, 1116-1128 (2012). 
45. Schaufeli, W.B., Maassen, G.H., Bakker, A.B. \& Sixma, H.J. Stability and change in burnout: A 10-year follow-up study among primary care physicians. Journal of Occupational and Organizational Psychology 84, 248-267 (2011).

46. Chapple, H., Shah, S., Caress, A.L. \& Kay, E.J. Exploring dental patients' preferred roles in treatment decision-making - a novel approach. Br Dent J 194, 321-327 (2003).

47. Richards, H.J., Benson, V., Donnelly, N. \& Hadwin, J.A. Exploring the function of selective attention and hypervigilance for threat in anxiety. Clinical Psychology Review 34, 1-13 (2014).

48. Kimble, M., et al. The impact of hypervigilance: Evidence for a forward feedback loop. Journal of Anxiety Disorders 28, 241-245 (2014).

49. Chambers, D.W. The role of dentists in dentistry. Journal of Dental Education 65, 1430-1440 (2001).

50. Moore, R. \& Brodsgaard, I. Dentists' perceived stress and its relation to perceptions about anxious patients. Community Dent Oral Epidemiol 29, 73-80 (2001).

51. Dillman, D.A. THE DESIGN AND ADMINISTRATION OF MAIL SURVEYS. Annual Review of Sociology 17, 225-249 (1991).

52. Edwards, P.J., et al. Methods to increase response to postal and electronic questionnaires. Cochrane Database Syst Rev, Mr000008 (2009).

53. Ben-Nun, P. Respondent Fatigue. in Encyclopedia of Survey Research Methods. (ed. Lavrakas, P.J.) (Sage Publications, Inc, Thousand Oaks, CA, 2008). 


\begin{tabular}{|c|c|c|c|c|c|c|}
\hline \multicolumn{5}{|c|}{ Summary of generic model } & \multicolumn{2}{|c|}{ Application to dentistry } \\
\hline $\begin{array}{l}\text { Level of } \\
\text { arousal }\end{array}$ & Description & $\begin{array}{l}\text { Type of } \\
\text { decision- } \\
\text { making }\end{array}$ & Sub-group & Quality of decision & Notes & $\begin{array}{l}\text { Examples from } \\
\text { Current study [Case Number] } \\
\text { Previous study }{ }^{7} \text { [Study Reference: Case } \\
\text { Number] }\end{array}$ \\
\hline \multirow[t]{2}{*}{ Low } & \multirow[t]{2}{*}{$\begin{array}{l}\text { Little decision- } \\
\text { making conflict and } \\
\text { stress because of } \\
\text { complacency about } \\
\text { potentially } \\
\text { unfavourable } \\
\text { consequences }\end{array}$} & \multirow[t]{2}{*}{ Unconflicted } & adherence & $\begin{array}{l}\text { Persistence with the } \\
\text { current course of action, } \\
\text { ignoring information and } \\
\text { risks }\end{array}$ & & $\begin{array}{l}\text { Patient who habitually turns up late doesn't } \\
\text { allow enough time to carry out all the planned } \\
\text { procedure. Should make new appointment or } \\
\text { place only temporary restoration but instead } \\
\text { try to complete full procedure anyway. [406] }\end{array}$ \\
\hline & & & change & $\begin{array}{l}\text { Uncritical adoption of the } \\
\text { most relevant or strongly } \\
\text { recommended course of } \\
\text { action }\end{array}$ & & $\begin{array}{l}\text { Patient suffering from pulpitis comes to the } \\
\text { practice and demands to have the tooth } \\
\text { removed as an emergency booking in for } 5 \\
\text { minutes. I agree to remove the tooth even if I } \\
\text { believe another approach would be better } \\
\text { option. [477] }\end{array}$ \\
\hline Moderate & $\begin{array}{l}\text { There is enough risk } \\
\text { and mental conflict } \\
\text { for the decision- } \\
\text { maker to be } \\
\text { moderately stressed } \\
\text { and thus to be alert } \\
\text { and efficient. } \\
\text { However, there is } \\
\text { the hope of a good } \\
\text { solution and enough } \\
\text { time to seek } \\
\text { information and } \\
\text { weigh the options. }\end{array}$ & Vigilant & & & & $\begin{array}{l}\text { Undertake clinical procedure first time. } \\
\text { Decisions slowing down, possibly search for } \\
\text { answers in books/internet/mentor if time } \\
\text { available, if not do what seems best or try to } \\
\text { gain time. [110] }\end{array}$ \\
\hline High & There is significant & Avoidant & Procrastination & When there is time to & This should be & Treating a patient who has complained about \\
\hline
\end{tabular}




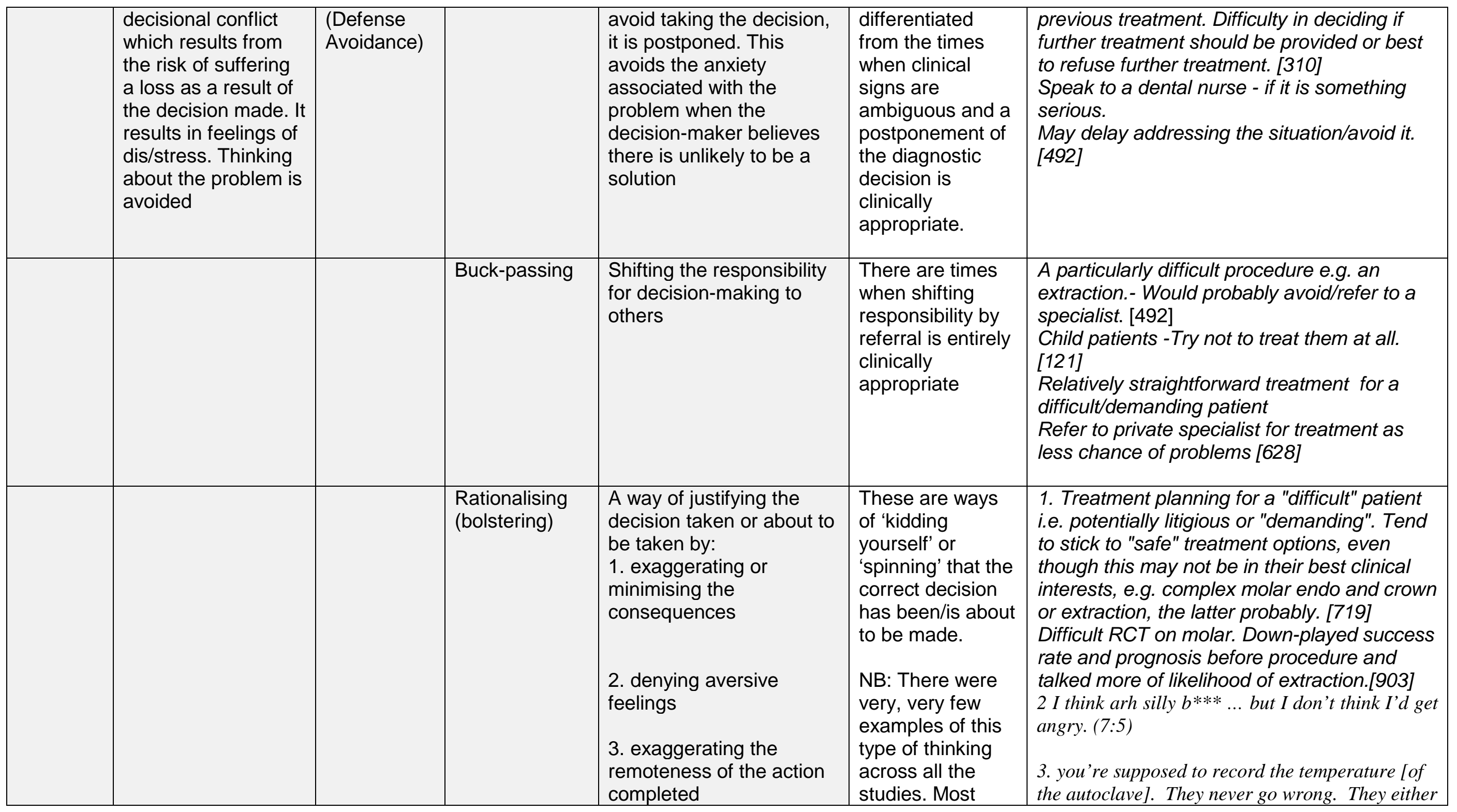




\begin{tabular}{|c|c|c|c|c|c|}
\hline & & & $\begin{array}{l}\text { 4. minimising social } \\
\text { responsibility } \\
\text { 5. minimising personal } \\
\text { responsibility }\end{array}$ & $\begin{array}{l}\text { examples gave } \\
\text { ethical choices in } \\
\text { these } \\
\text { circumstances }\end{array}$ & $\begin{array}{l}\text { achieve temperature or they don't. And you've } \\
\text { got a little disc to put in. (7: 8) } \\
\text { 4. not doing things to the absolute best standard } \\
\text { possible - maybe because the materials are } \\
\text { expensive or because there ... isn't enough time to } \\
\text { do it perhaps as well as you might be able to } \\
\text { [because of the NHS fee structure]. I think most } \\
\text { NHS dentists would say that, they would feel like } \\
\text { that [7: 4]. } \\
\text { 4. Under pressure (daily/weekly) to achieve UDA } \\
\text { targets, from corporate and primary care } \\
\text { organisations. } \\
\text { Biased towards simple/less costly/less time } \\
\text { consuming treatments when explaining options } \\
\text { (NHS) to the patient. } \\
\text { [694] } \\
5 \text {. After splitting } 2 \text { extractions across } 2 \text { courses of } \\
\text { treatment you sort of try and justify to yourself- } \\
\text { oh no, I don't think it's an unreasonable thing that } \\
\text { you've done. And you know, it's better for her to } \\
\text { just come back again in a couple of months and } \\
\text { let it heal and stuff, you kind of - you can justify it } \\
\text { to yourself (7: 4). }\end{array}$ \\
\hline Very high & $\begin{array}{l}\text { There are very high } \\
\text { levels of decisional } \\
\text { conflict; threat cues } \\
\text { are very salient and } \\
\text { insufficient time to } \\
\text { escape the } \\
\text { anticipated serious } \\
\text { losses. }\end{array}$ & $\begin{array}{l}\text { Hyper- } \\
\text { vigilance }\end{array}$ & $\begin{array}{l}\text { Can be as severe as } \\
\text { panic. } \\
\text { There is reduced } \\
\text { information processing, a } \\
\text { failure to consider all the } \\
\text { options available and an } \\
\text { increased likelihood of } \\
\text { impulsive decision- } \\
\text { making. }\end{array}$ & & $\begin{array}{l}\text { Running late - You have to move up several } \\
\text { gears in thinking and actions - decision- } \\
\text { making has become akin to jumping in the } \\
\text { deep end - decide - hope - pray and } \\
\text { exhausted later. [23] } \\
\text { Anxious about illness of family member. } \\
\text { Distracted and possibly not considering all } \\
\text { alternatives.[73] }\end{array}$ \\
\hline
\end{tabular}




\begin{tabular}{|l|l|l|l|l|l|}
\hline \multicolumn{2}{|l|}{ Table 2 } & Return rates for questionnaires \\
\hline & Sent & Returned & $\begin{array}{l}\text { Return to } \\
\text { Sender }\end{array}$ & Not eligible & Usable \\
\hline $\mathbf{1}^{\text {st }}$ send & 792 & 123 & 19 & $\begin{array}{l}10 \text { retired } \\
7 \text { secondary } \\
\text { care } \\
2 \text { management } \\
1 \text { academic } \\
1 \text { refusal }\end{array}$ & 102 \\
\hline $\begin{array}{l}\text { 2nd } \\
\text { send }\end{array}$ & 667 & 97 & 26 & $\begin{array}{l}8 \text { retired } \\
\text { s secondary } \\
\text { care }\end{array}$ & 85 \\
\hline
\end{tabular}




\begin{tabular}{|l|l|l|}
\hline \multicolumn{1}{|l|}{ Table 3 Demographics of participants } & $\begin{array}{l}\text { Missing } \\
\text { data }\end{array}$ \\
\hline Gender & $\begin{array}{l}42 \%(79) \text { female } \\
57 \%(107) \text { male }\end{array}$ & 1 \\
\hline Type of Practice & $\begin{array}{l}89 \%(167) \text { General Dental Service, } \\
5 \%(9) \text { Community Dental Service, } \\
3 \%(5) \text { Armed Forces }\end{array}$ & 7 \\
\hline Corporate & $\begin{array}{l}67 \%(125) \text { Non-corporate } \\
32 \%(60) \text { Corporate }\end{array}$ & 2 \\
\hline NHS / Private & $\begin{array}{l}58 \%(108)>75 \% \text { NHS Practice } \\
\text { Practice Ratio }\end{array}$ & 1 \\
& $\begin{array}{l}29 \%(55)>75 \% \text { Private Practice } \\
1 \%(21) \text { Mixed Practice }\end{array}$ & \\
\hline Specialism & $\begin{array}{l}37 \%(69) \text { Yes forces } \\
61 \%(114) \text { No }\end{array}$ & 4 \\
\hline Working hours & $\begin{array}{l}5 \%(9)>45 \text { hours a week } \\
44 \%(82) 36-45 \text { hours a week } \\
37 \%(69) 25-35 \text { hours a week } \\
14 \%(27)<25 \text { hours a week }\end{array}$ & 0 \\
\hline Year Qualified & Average 1993 (S.E. 0.89) & 3 \\
\hline $\begin{array}{l}\text { Years working in } \\
\text { primary care }\end{array}$ & Average 17.1 years (S.E. 0.91) & 4 \\
\hline
\end{tabular}




\begin{tabular}{|c|c|c|c|c|}
\hline & Situation & $\begin{array}{l}\text { DACSS-R } \\
\text { How much } \\
\text { anxiety do the } \\
\text { following } \\
\text { situations cause } \\
\text { you in primary } \\
\text { care dental } \\
\text { practice? (0 not } \\
\text { at all - } 10 \text { most } \\
\text { intense emotion } \\
\text { you can } \\
\text { experience) } \\
\text { Mean, } \\
\text { SD (N) }\end{array}$ & \multicolumn{2}{|c|}{$\begin{array}{l}\text { DASS-C } \\
\text { Answers split according to those } \\
\text { who indicated the anxiety } \\
\text { changes something about the way } \\
\text { they work. } \\
\text { Mean, } \\
\text { SD (N) }\end{array}$} \\
\hline & & & Yes & No \\
\hline 1 & $\begin{array}{l}\text { You have to undertake a } \\
\text { clinical procedure for the first } \\
\text { time }\end{array}$ & $\begin{array}{l}5.91 \\
2.58(187)\end{array}$ & $\begin{array}{l}6.80 \\
2.16(109)\end{array}$ & $\begin{array}{l}4.65^{\star \star *} \\
2.64(74)\end{array}$ \\
\hline 2 & $\begin{array}{l}\text { You have to undertake a } \\
\text { particularly difficult clinical } \\
\text { procedure }\end{array}$ & $\begin{array}{l}5.94 \\
2.49(187)\end{array}$ & $\begin{array}{l}7.19 \\
1.80(93)\end{array}$ & $\begin{array}{l}4.65^{\star \star \star} \\
2.45(89)\end{array}$ \\
\hline 3 & $\begin{array}{l}\text { A patient complains about the } \\
\text { difficulty of getting } \\
\text { appointments }\end{array}$ & $\begin{array}{l}3.51 \\
2.39(187)\end{array}$ & $\begin{array}{l}5.13 \\
2.33(56)\end{array}$ & $\begin{array}{l}2.85^{\star \star \star} \\
2.08(126)\end{array}$ \\
\hline 4 & $\begin{array}{l}\text { Something goes wrong on a } \\
\text { patient who is 'difficult' }\end{array}$ & $\begin{array}{l}7.00 \\
2.29(187)\end{array}$ & $\begin{array}{l}7.97 \\
1.82(103)\end{array}$ & $\begin{array}{l}5.69 * \star \star \\
2.19(78)\end{array}$ \\
\hline 5 & $\begin{array}{l}\text { Treating patients who are very } \\
\text { anxious/phobic }\end{array}$ & $\begin{array}{l}5.08 \\
2.81(187)\end{array}$ & $\begin{array}{l}6.46 \\
2.44(85)\end{array}$ & $\begin{array}{l}3.83^{\star \star \star} \\
2.60(94)\end{array}$ \\
\hline 6 & $\begin{array}{l}\text { A patient doesn't like the } \\
\text { appearance of the crowns/ } \\
\text { bridgework you are about to fit, } \\
\text { which are really very good }\end{array}$ & $\begin{array}{l}6.21 \\
2.47(187)\end{array}$ & $\begin{array}{l}7.29 \\
2.06(77)\end{array}$ & $\begin{array}{l}5.43^{\star \star \star} \\
2.50(103)\end{array}$ \\
\hline 7 & Running late & $\begin{array}{l}5.95 \\
2.72(187)\end{array}$ & $\begin{array}{l}7.11 \\
2.15(97)\end{array}$ & $\begin{array}{l}4.60 * \star \star \\
2.74(83)\end{array}$ \\
\hline 8 & $\begin{array}{l}\text { There is a conflict between the } \\
\text { treatment you are advising and } \\
\text { what the patient is requesting. }\end{array}$ & $\begin{array}{l}4.98 \\
2.51(187)\end{array}$ & $\begin{array}{l}6.49 \\
2.20(67)\end{array}$ & $\begin{array}{l}4.07^{\star \star \star *} \\
2.31(111)\end{array}$ \\
\hline 9 & $\begin{array}{l}\text { You believe you have } \\
\text { explained the } \\
\text { treatment/options to a patient } \\
\text { and they say later that they } \\
\text { didn't understand what you } \\
\text { were going to do. }\end{array}$ & $\begin{array}{l}5.48 \\
2.62(187)\end{array}$ & $\begin{array}{l}6.76 \\
2.22(70)\end{array}$ & $\begin{array}{l}4.65^{\star \star \star} \\
2.59(106)\end{array}$ \\
\hline 10 & $\begin{array}{l}\text { Something unfortunate } \\
\text { happens clinically such as a } \\
\text { tooth fractures at the gingival } \\
\text { margin when placing a rubber } \\
\text { dam clamp. }\end{array}$ & $\begin{array}{l}6.10 \\
2.50(187)\end{array}$ & $\begin{array}{l}7.08 \\
2.05(86)\end{array}$ & $\begin{array}{l}5.21^{\star \star \star} \\
2.56(89)\end{array}$ \\
\hline
\end{tabular}




\begin{tabular}{|c|c|c|c|c|}
\hline 11 & There is a medical emergency & $\begin{array}{l}7.40 \\
2.47(187)\end{array}$ & $\begin{array}{l}8.47 \\
1.83(86)\end{array}$ & $\begin{array}{l}6.47^{\star \star \star} \\
2.55(90)\end{array}$ \\
\hline 12 & $\begin{array}{l}\text { You have to speak to a dental } \\
\text { nurse about changing her } \\
\text { procedures in the dental } \\
\text { surgery }\end{array}$ & $\begin{array}{l}4.60 \\
2.69(187)\end{array}$ & $\begin{array}{l}5.83 \\
2.42(52)\end{array}$ & $\begin{array}{l}4.16^{\star \star \star} \\
2.62(124)\end{array}$ \\
\hline 13 & $\begin{array}{l}\text { You receive a solicitor's letter } \\
\text { alleging negligence. }\end{array}$ & $\begin{array}{l}8.37 \\
2.13(187)\end{array}$ & $\begin{array}{l}9.00 \\
1.77(100)\end{array}$ & $\begin{array}{l}7.71^{\star \star \star} \\
2.20(76)\end{array}$ \\
\hline 14 & $\begin{array}{l}\text { You are about to fit a complex } \\
\text { and expensive piece of crown } \\
\& \text { bridge work }\end{array}$ & $\begin{array}{l}5.63 \\
2.67(187)\end{array}$ & $\begin{array}{l}7.26 \\
2.26(46)\end{array}$ & $\begin{array}{l}5.10^{\star \star \star} \\
2.53(128)\end{array}$ \\
\hline 15 & $\begin{array}{l}\text { A new patient tells you that } \\
\text { their last } 3 \text { dentists never got } \\
\text { them numb and you have to do } \\
\text { a deep restoration }\end{array}$ & $\begin{array}{l}4.46 \\
2.78(187)\end{array}$ & $\begin{array}{l}6.22 \\
2.27(50)\end{array}$ & $\begin{array}{l}3.78^{\star \star \star} \\
2.65(124)\end{array}$ \\
\hline 16 & $\begin{array}{l}\text { A new, nervous, } 5 \text { year old } \\
\text { child patient has toothache } \\
\text { and needs a lower second } \\
\text { deciduous molar extracting at } \\
\text { his/her first visit. }\end{array}$ & $\begin{array}{l}5.47 \\
2.98(187)\end{array}$ & $\begin{array}{l}6.78 \\
2.51(55)\end{array}$ & $\begin{array}{l}4.88^{\star \star \star} \\
3.03(117)\end{array}$ \\
\hline 17 & $\begin{array}{l}\text { I don't feel in control of a } \\
\text { clinical situation in the surgery }\end{array}$ & $\begin{array}{l}6.51 \\
2.80(187)\end{array}$ & $\begin{array}{l}7.41 \\
2.41(92)\end{array}$ & $\begin{array}{l}5.54^{\star \star \star} \\
2.84(80)\end{array}$ \\
\hline 18 & $\begin{array}{l}\text { To carry out the most ethical } \\
\text { treatment will result in a } \\
\text { financial loss }\end{array}$ & $\begin{array}{l}3.93 \\
2.83(156)\end{array}$ & $\begin{array}{l}5.75 \\
2.69(36)\end{array}$ & $\begin{array}{l}3.33^{\star * \star} \\
2.60(106)\end{array}$ \\
\hline 19 & $\begin{array}{l}\text { To carry out the most } \\
\text { efficacious treatment would be } \\
\text { (too) costly to the patient }\end{array}$ & $\begin{array}{l}4.50 \\
2.69(157)\end{array}$ & $\begin{array}{l}5.75 \\
2.62(53)\end{array}$ & $\begin{array}{l}3.83^{\star \star \star} \\
2.46(89)\end{array}$ \\
\hline 20 & $\begin{array}{l}\text { There is a conflict between } \\
\text { NHS/private rules and clinical } \\
\text { choices }\end{array}$ & $\begin{array}{l}4.47 \\
3.05(149)\end{array}$ & $\begin{array}{l}6.33 \\
2.71(39)\end{array}$ & $\begin{array}{l}3.78^{\star \star \star} \\
2.85(96)\end{array}$ \\
\hline \multicolumn{5}{|c|}{$\star \star \star ~ p<.001$} \\
\hline
\end{tabular}




\begin{tabular}{|c|c|c|c|c|}
\hline \multirow[b]{2}{*}{ Items from DACSS } & \multicolumn{4}{|c|}{ Component } \\
\hline & 1 & 2 & 3 & 4 \\
\hline $\begin{array}{l}\text { R9. You believe you have explained the treatment / } \\
\text { options to a patient and they say later that they didn't } \\
\text { understand what you were going to do. }\end{array}$ & 0.80 & & & \\
\hline $\begin{array}{l}\text { R6. A patient doesn't like the appearance of the crowns / } \\
\text { bridgework you are about to fit, which are really very } \\
\text { good. }\end{array}$ & 0.77 & & & \\
\hline $\begin{array}{l}\text { R8. There is a conflict between the treatment you are } \\
\text { advising and what the patient is requesting. }\end{array}$ & 0.73 & & & \\
\hline R7. Running late. & 0.66 & & & \\
\hline R13. You receive a solicitor's letter alleging negligence. & 0.65 & & & \\
\hline $\begin{array}{l}\text { R10. Something unfortunate happens clinically such as a } \\
\text { tooth fractures at the gingival margin when placing a } \\
\text { rubber dam clamp. }\end{array}$ & 0.65 & 0.42 & & \\
\hline $\begin{array}{l}\text { R14. You are about to fit a complex and expensive piece } \\
\text { of crown \& bridge work. }\end{array}$ & 0.51 & 0.41 & 0.43 & \\
\hline $\begin{array}{l}\text { R1. You have to undertake a clinical procedure for the } \\
\text { first time. }\end{array}$ & & 0.79 & & \\
\hline $\begin{array}{l}\text { R17. I don't feel in control of a clinical situation in the } \\
\text { surgery. }\end{array}$ & & 0.75 & & \\
\hline R11. There is a medical emergency. & & 0.73 & & \\
\hline $\begin{array}{l}\text { R12. You have to speak to a dental nurse about changing } \\
\text { her procedures in the dental surgery. }\end{array}$ & & 0.46 & & \\
\hline $\begin{array}{l}\text { R16. A new, nervous, } 5 \text { year old child patient has } \\
\text { toothache and needs a lower second deciduous molar } \\
\text { extracting at his/her first visit. }\end{array}$ & & & 0.80 & \\
\hline $\begin{array}{l}\text { R15. A new patient tells you that their last } 3 \text { dentists } \\
\text { never got them numb and you have to do a deep } \\
\text { restoration. }\end{array}$ & & & 0.71 & \\
\hline R5. Treating patients who are very anxious / phobic. & & & 0.67 & \\
\hline $\begin{array}{l}\text { R20. There is a conflict between NHS / private rules and } \\
\text { clinical choices. }\end{array}$ & & & & 0.82 \\
\hline $\begin{array}{l}\text { R19. To carry out the most efficacious treatment would be } \\
\text { (too) costly to the patient. }\end{array}$ & 0.40 & & & 0.74 \\
\hline $\begin{array}{l}\text { R18. To carry out the most ethical treatment will result in } \\
\text { a financial loss. }\end{array}$ & & & 0.43 & 0.73 \\
\hline Eigenvalues & 8.50 & 1.27 & 1.05 & 0.97 \\
\hline$\%$ of variance & 50.00 & 7.48 & 6.19 & 5.71 \\
\hline Cronbach's a & .91 & .79 & .84 & .80 \\
\hline
\end{tabular}


Table 6 Mean anxiety levels reported by dentists according to the post PCA components of the DACSS-R

\begin{tabular}{|l|l|}
\hline & $\begin{array}{l}\text { Mean ratings on DACSS-R } \\
(\text { S.D.) (N=149) }\end{array}$ \\
\hline Component 1: Uncertainties in clinical practice & $6.09(2.04)$ \\
\hline Component 2: Threats to sense of control & $6.08(2.11)$ \\
\hline Component 3: Challenging patients & $5.08(2.53)$ \\
\hline Component 4: Ethical dilemmas & $4.29(2.43)$ \\
\hline Average across components & $5.38(1.92)$ \\
\hline
\end{tabular}




\begin{tabular}{|c|c|}
\hline Scale & $\begin{array}{l}\text { Pearson's } \\
\text { correlation }\end{array}$ \\
\hline MDMQ - Decision self-esteem & $-.443^{\star \star \star}$ \\
\hline MDMQ - Vigilance & -.050 \\
\hline MDMQ - Buck passing & $.372^{\star \star \star}$ \\
\hline MDMQ - Procrastination & $.308^{\star \star \star}$ \\
\hline MDMQ - Hypervigilance & $.554^{\star \star \star}$ \\
\hline MBI - Emotional Exhaustion & $.534^{\star \star \star}$ \\
\hline MBI - Depersonalisation & $.294^{\star \star \star}$ \\
\hline MBI - Personal Accomplishment & $-.266^{\star \star \star}$ \\
\hline DUQ - Diagnostic Action & .165 \\
\hline DUQ - Diagnostic Reasoning & .010 \\
\hline
\end{tabular}




\begin{tabular}{|c|c|c|}
\hline & Mean (S.D.) & Mean (SD) \\
\hline $\begin{array}{l}\text { Melbourne Decision Making } \\
\text { Questionnaire }\end{array}$ & & Mann et al, $1997^{27}$ \\
\hline Decision Self-Esteem & $9.79(2.02)$ & $8.81(2.42)$ \\
\hline Vigilance & $10.36(1.79)$ & $9.41(2.22)$ \\
\hline Buck-passing & $3.05(2.63)$ & $4.87(2.93)$ \\
\hline Procrastination & $1.76(1.88)$ & $3.88(2.39)$ \\
\hline Hypervigilance & $3.13(2.12)$ & $4.61(2.26)$ \\
\hline Maslach Burnout Inventory & & $\begin{array}{l}\text { te Brake et al } 2001^{11} \\
\text { (Netherlands) }\end{array}$ \\
\hline Emotional Exhaustion & $2.44(1.42)$ & $1.8(1.1)$ \\
\hline Depersonalisation & $1.30(1.06)$ & $\begin{array}{l}\text { Men 1.3(0.8) } \\
\text { Women } 1.0(0.7)\end{array}$ \\
\hline Personal Accomplishment & 4.83 & $4.4(0.9)$ \\
\hline \multicolumn{3}{|l|}{ Dealing with Uncertainty } \\
\hline Diagnostic Action & $26.67(5.39)$ & ----- \\
\hline Diagnostic Reasoning & $16.75(3.85)$ & ----- \\
\hline $\begin{array}{l}\text { Dentists Anxiety in Clinical } \\
\text { Situations Scale-R }\end{array}$ & $5.39(1.92)$ & $\begin{array}{ll}---- \\
\end{array}$ \\
\hline & & \\
\hline
\end{tabular}




\begin{tabular}{|c|c|c|c|}
\hline & B & S.E. B. & $\boldsymbol{\beta}$ \\
\hline \multicolumn{4}{|l|}{ Step 1} \\
\hline MDMQ Hypervigilance & 0.50 & 0.06 & $0.55^{\star \star}$ \\
\hline \multicolumn{4}{|l|}{ Step 2} \\
\hline MDMQ Hypervigilance & 0.35 & 0.07 & $0.38^{\star \star}$ \\
\hline MBI Emotional Exhaustion & 0.46 & 0.10 & $0.34^{\star *}$ \\
\hline \multicolumn{4}{|l|}{ Step 3} \\
\hline MDMQ Hypervigilance & 0.26 & 0.08 & $0.29^{*}$ \\
\hline MBI Emotional Exhaustion & 0.45 & 0.10 & $0.33^{* *}$ \\
\hline MDMQ Decision Self-Esteem & -0.18 & 0.07 & $-0.19 *$ \\
\hline \multicolumn{4}{|c|}{$\begin{array}{l}\text { Note: } R^{2}=0.31 \text { for Step } 1, \Delta R^{2}=0.09 \text { for Step } 2(p<.001), \Delta R^{2}=0.02 \text { for Step } 3 \\
(p<.05) . \\
\star \star *<<.001,{ }^{*} p<.05 \text {. }\end{array}$} \\
\hline
\end{tabular}




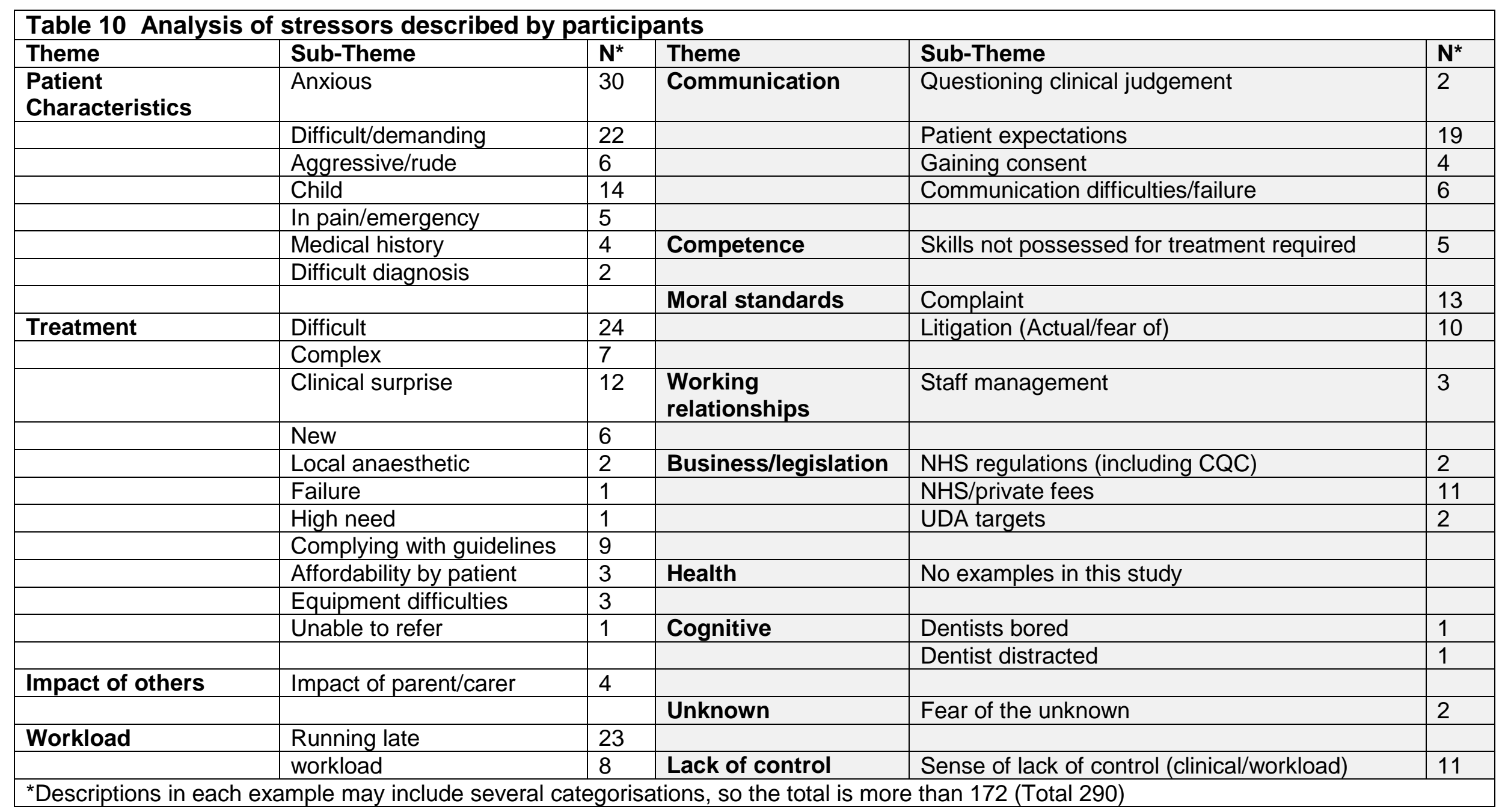




\begin{tabular}{|c|c|c|c|c|}
\hline \multicolumn{2}{|c|}{ Effect on clinical decision making } & \multirow{2}{*}{$\begin{array}{l}\text { No. } \\
\text { (n) }\end{array}$} & \multirow{2}{*}{$\begin{array}{l}\text { Example [respondent ID number] } \\
\text { 'likely to choose simpler treatment' [22] }\end{array}$} & \multirow{2}{*}{$\begin{array}{l}\text { Typical provoking situation } \\
\text { When treating anxious patients } \\
\end{array}$} \\
\hline \multirow{6}{*}{$\begin{array}{l}\text { Modify } \\
\text { treatment plan }\end{array}$} & Simplify & & & \\
\hline & $\begin{array}{l}\text { To match patient } \\
\text { expectations }\end{array}$ & 9 & $\begin{array}{l}\text { So I might end up doing treatment I would not } \\
\text { have suggested in the first place, but it is the } \\
\text { one the patient is requesting. [102] }\end{array}$ & In response to demanding patients \\
\hline & Manage patient not mouth & 14 & 'make it more appropriate for the patient.' [24] & $\begin{array}{l}\text { In response to anxious patients and clinical } \\
\text { surprises and often involved the } \\
\text { prescription of antibiotics as a holding } \\
\text { treatment }\end{array}$ \\
\hline & So as not to lose money & 4 & $\begin{array}{l}\text { It would in effect make it difficult financially to do } \\
\text { a cobalt chrome for the patient as would 'cost' } \\
\text { me }>£ 50 \text { in real terms [693] }\end{array}$ & $\begin{array}{l}\text { NHS treatments which cost the practice } \\
\text { money }\end{array}$ \\
\hline & Defensive & 6 & $\begin{array}{l}\text { 'I prefer not to do nothing that could cause } \\
\text { someone to complain and sue me, even when } \\
\text { I'm sure that what I was planning was the best } \\
\text { to the patient.' [116] }\end{array}$ & $\begin{array}{l}\text { In response to an actual } \\
\text { complaint/litigation or simply to avoid it }\end{array}$ \\
\hline & $\begin{array}{l}\text { To match clinical need, } \\
\text { match to clinical } \\
\text { competence, be flexible, } \\
\text { to match patient's ability } \\
\text { to pay. Not change } \\
\text { treatment plan to meet } \\
\text { patient demands }\end{array}$ & $\leq 4$ & & \\
\hline Refer & $\begin{array}{l}\text { Proactive - in house or to } \\
\text { another practice }\end{array}$ & 19 & $\begin{array}{l}\text { 'Refer to private specialist for treatment as less } \\
\text { chance of problems' [169] } \\
\text { 'To Involve one of my colleagues to convince } \\
\text { patient of the sequence of treatment and give } \\
\text { the patient opportunity to decide and consent.' } \\
\text { [517] }\end{array}$ & $\begin{array}{l}\text { Out of practice - Anxious patients, in } \\
\text { particular, children, or children with high } \\
\text { treatment needs. Difficult treatments eg } \\
\text { RCT, surgery } \\
\text { In house - usually in response to } \\
\text { failed/compromised treatment, particularly } \\
\text { with children or adults where a lack of trust } \\
\text { is implied }\end{array}$ \\
\hline
\end{tabular}




\begin{tabular}{|c|c|c|c|c|}
\hline & reactive & 8 & $\begin{array}{l}\text { 'Treat Abscess/dress then refer for extraction.' } \\
\text { [517] }\end{array}$ & $\begin{array}{l}\text { In response to failed/compromised } \\
\text { treatment, particularly with children or } \\
\text { adults where a lack of trust is implied }\end{array}$ \\
\hline & Find another dentist & $\leq 4$ & & \\
\hline \multirow[t]{7}{*}{$\begin{array}{l}\text { Effects on } \\
\text { treatment }\end{array}$} & Quality & $\leq 4$ & $\begin{array}{l}\text { May not finish restoration to best ability. } \\
\text { Restoration will not last as long.[27] }\end{array}$ & Usually in response to running late \\
\hline & Reduce quantity & 7 & $\begin{array}{l}\text { Reduce treatment planned for that visit to try to } \\
\text { catch up time. [248] }\end{array}$ & In response to running late \\
\hline & Abandon & 8 & I prefer to give up the treatment [777] & $\begin{array}{l}\text { In relation to not being in control in the } \\
\text { surgery because of patient anxiety, } \\
\text { clinically difficult situations, communication } \\
\text { problems or, in this case, the lack of the } \\
\text { correct forceps }\end{array}$ \\
\hline & Delay & 7 & $\begin{array}{l}\text { More likely to postpone treatment that can be } \\
\text { postponed without harm to patients health, i.e. } \\
\text { when doing check-up and patient is returning for } \\
\text { restorations, I will put off the time-consuming } \\
\text { scaling onto next visit.[627] } \\
\text { Defer treatment until diagnosis more clear/ } \\
\text { patient had time to think.[201] }\end{array}$ & $\begin{array}{l}\text { In response to running late or difficult } \\
\text { clinical situations. }\end{array}$ \\
\hline & $\begin{array}{l}\text { Avoidance (other than by } \\
\text { referral) }\end{array}$ & 6 & $\begin{array}{l}\text { It has made me cautious and more anxious at } \\
\text { treating new patients, particularly those } \\
\text { unhappy with their previous GDP and made me } \\
\text { try to avoid treatment unless needed [729] }\end{array}$ & $\begin{array}{l}\text { Avoidance of treatment that the dentist } \\
\text { does not feel confident at performing. }\end{array}$ \\
\hline & Extra time & 20 & $\begin{array}{l}\text { I just increase the time I have for the treatment } \\
\text { which allows me to manage the situation better. } \\
\text { [12] }\end{array}$ & $\begin{array}{l}\text { Particularly for anxious patients. Also } \\
\text { complex or new treatments, difficult } \\
\text { patients particularly where communication } \\
\text { difficulties are expected }\end{array}$ \\
\hline & $\begin{array}{l}\text { Rushed, clinical error, } \\
\text { replace work }\end{array}$ & $\leq 4$ & & \\
\hline Changes to & Modify communication & 19 & It made me warn every patient who needed & 1. Positively, with very anxious patients, \\
\hline
\end{tabular}




\begin{tabular}{|c|c|c|c|c|}
\hline $\begin{array}{l}\text { procedures } \\
\text { and } \\
\text { interpersonal } \\
\text { interactions }\end{array}$ & & & $\begin{array}{l}\text { extraction of an upper molar of the risk that a } \\
\text { root may end up in the sinus, even though the } \\
\text { risk is very small and this had effect of } \\
\text { increasing patient's anxiety about the } \\
\text { procedure. [181] } \\
\text { Ensure spend more time listening to patients' } \\
\text { requirements to see if we can negotiate a } \\
\text { treatment plan we are both happy with. [436] }\end{array}$ & $\begin{array}{l}\text { with patients who are 'difficult' with } \\
\text { unrealistic expectations. 2. As a defensive } \\
\text { response to litigation, which could } \\
\text { sometimes have detrimental } \\
\text { consequences. Most modification was in } \\
\text { terms of information giving. } \\
\text { One example of improved listening }\end{array}$ \\
\hline & Reflection/audit & 7 & $\begin{array}{l}\text { I would reflect on what went wrong the first time } \\
\text { and spend extra time planning/making sure the } \\
\text { second time it was better.[231[ } \\
\text { It has made me more aware of new patient } \\
\text { medical issues and getting advice, help, } \\
\text { guidance sooner [568] }\end{array}$ & $\begin{array}{l}\text { Reflective learning was used when } \\
\text { communication or clinical situations had } \\
\text { not been ideal }\end{array}$ \\
\hline & Don't charge/refund fee & 5 & $\begin{array}{l}\text { Patient keeps complaining about new denture } \\
\text { and keeps coming back even if there is no } \\
\text { obvious problem.[492] }\end{array}$ & $\begin{array}{l}\text { When patient complains about outcome, } \\
\text { even when treatment apparently } \\
\text { acceptable }\end{array}$ \\
\hline & $\begin{array}{l}\text { Improve } \\
\text { planning/preparation }\end{array}$ & 4 & $\begin{array}{l}\text { Spend extra time planning/making sure the } \\
\text { second time it was better. [231] }\end{array}$ & $\begin{array}{l}\text { In response to something which had not } \\
\text { gone to plan or before difficult treatments }\end{array}$ \\
\hline & $\begin{array}{l}\text { Avoid patient (specific } \\
\text { individual or generic) }\end{array}$ & 5 & $\begin{array}{l}\text { I pulled a 'sickie' when I knew she was next in. } \\
\text { [607] }\end{array}$ & $\begin{array}{l}\text { In response to previously stressful } \\
\text { encounter with difficult/demanding patient. }\end{array}$ \\
\hline & $\begin{array}{l}\text { Write good/better notes, } \\
\text { modify protocols/ } \\
\text { procedures, belt and } \\
\text { braces consent, avoid } \\
\text { disciplining staff, avoid } \\
\text { similar treatments, act, } \\
\text { seek peer support, } \\
\text { undertake further training, } \\
\text { conduct audit }\end{array}$ & $\leq 4$ & & \\
\hline $\begin{array}{l}\text { Effects on } \\
\text { decision- }\end{array}$ & Quick decisions & 4 & $\begin{array}{l}\text { 'decision making has become akin to jumping in } \\
\text { the deep end - decide - hope - pray' [23] }\end{array}$ & When running late. \\
\hline
\end{tabular}


Reduced attention, delay

decision, worry, careful

decision, indecisive,

distracted

$\leq 3$

$\leq 3$ 